\title{
AN OVERVIEW OF THE DISTRIBUTION OF THE PARABATHYNELLIDAE (CRUSTACEA, SYNCARIDA BATHYNELLACEA) ON THE IBERIAN PENINSULA AND BALEARIC ISLANDS
}

\author{
A. I. Camacho*
}

\begin{abstract}
This paper reviews all the knowledge on the presence and distribution of 26 species of the family Parabathynellidae Noodt, 1964 (Crustacea, Syncarida, Bathynellacea) on the Iberian Peninsula and Balearic Islands. The different genera, subgenera and species distributions are subjected to a basic analysis. The presence of these taxa in different subterranean aquatic habitats (caves, springs, wells and interstitial environment) is also discussed. The most sampled habitat was the interstitial environment (45\%); the least sampled habitat was springs (5\%). The most commonly found genus was Iberobathynella Schminke, 1973 (54\%) and the rarest was Guadalopebathynella Camacho \& Serban, 1998 (0.7\%)

All the knowledge on these taxa in the study area, in Europe and in the world is compared and evaluated. More species of the Parabathynellidae live on the Iberian Peninsula and Balearic Islands than in any other part of the world (26 species). Iberobathynella is a highly diversified genus endemic to the Iberian peninsula. Its diversity is comparable to another genus in the order, Hexabathynella Schminke, 1972, which also has 18 described species. However, Hexabathynella has a cosmopolitan distribution.
\end{abstract}

Key words: Crustacea, Syncarida, Parabathynellidae, Distribution, Faunistics, subterranean water, Spain, Portugal.

\section{RESUMEN}

Distribución de la familia Parabathynellidae (Crustacea, Syncarida, Bathynellacea) en la Península Ibérica e Islas Baleares

En este trabajo se reune y actualiza el conocimiento acerca de la presencia y distribución de 26 especies de batinelas de la familia Parabathynellidae (Crustacea, Syncarida, Bathynellacea) en la Peninsula Ibérica y las Islas Baleares. Se analiza de forma crítica la distribución de los diferentes géneros, subgéneros y especies y se discute acerca de la presencia de los mismos en diferentes habitat acuáticos subterráneos (cuevas, fuentes o surgencias, pozos y medio intersticial asociado a ríos epigeos). El mayor número de puntos de muestreo corresponde al medio intersticial (45\% del total) y en él se encuentran los cinco géneros presentes en el área de estudio; las surgencias constituyen el conjunto con menos puntos de muestreo (5\%) y en ellas sólo se encuentran los géneros Iberobathynella $(86 \%)$ y Hexaiberobathynella Camacho \& Serban, 1998 (14\%). El género Iberobathynella es el más común (54\% de las muestras) y vive en todos los medios. El género Guadalopebathynella sólo se ha encontrado en el medio intersticial de un río.

Se valora comparativamente el conocimiento de estos taxa en el área estudiada, en Europa y en el mundo. En la Península Ibérica y las Islas Baleares vive el mayor porcentaje de especies de todo el mundo (24\%) y todas ellas son endémicas de esta zona. El género Iberobathynella, endémico de la Península Ibérica, cuenta con 18 especies conocidas y tal diversificación sólo se da, en todo el orden, dentro del género Hexabathynella (18 especies) que es el único género cosmopolita de Bathynellacea.

Palabras clave: Crustacea, Syncarida, Parabathynellidae, Distribución, Faunística, agua subterránea, España, Portugal. 


\section{Introduction}

The Order Bathynellacea Chappuis, 1915, is widely distributed on the Iberian Peninsula and the Balearic Islands. This is the area of the World where most species of this crustacean group are known. The two families described in the order, Parabathynellidae Noodt, 1964 and Bathynellidae Grobben, 1905, are highly diversified in Portugal and Spain. In the rest of Europe only the Bathynellidae has a similar number of known species.

Twenty-six species of Parabathynellidae are known and a similar number of Bathynellidae to date on the Iberian Peninsula and Balearic Islands, but most of the latter have not yet been described. The Parabathynellidae comprises 18 species of Iberobathynella; one species of Guadalopebathynella; two species of Hexaiberobathynella; two species of Paraiberobathynella Camacho \& Serban, 1998; and three species of Hexabathynella Schminke, 1972 (the only cosmopolitan genus in the order Bathynellacea).

The distribution of the Parabathynellidae family in this area is very extensive and covers the whole of the Peninsula and the islands of Mallorca and menorca (Pretus, 1991). Some of the species are found in many different sites, often placed considerably apart, while other species inhabit very limited areas, some even being known from a single location only. Subterranean water sensu lato (i.e. caves: gours, pools, lakes, subterranean rivers and springs; and in unconsolidated sediments: wells and the hyporheic and intersticial realms) is the only habitat where bathynells live. This environment is poorly known on the Iberian Peninsula as well as in Europe and the world. But, despite this, we consider that the current knowledge on the distribution of 26 species in 139 different places, in four habitats, is such that it constitutes a body of data that is of considerable importance and now is the time that it should be revised, updated and compared critically from a faunistic point of view.

It is important to bear in mind that in Europe, apart from the Iberian Peninsula, only two genera of the Parabathynellidae family have been found. One of these, Parabathynella Chappuis, 1926, has only two species, which are widely distributed in France and Central Europe. The other genus, Hexabathynella, which is the only cosmopolitan genus in the order, has five species in Bulgaria and one in Corsica. Given that Parabathynella never crossed the Pyrenees, Hexabathynella has three different species on the Iberian Peninsula, and that as much as four endemic genera are known from this
Table 1.- Recognized names of taxa and corresponding taxonomic authories for all members of the Family Parabathynellidae of the Iberian Peninsula and Balearic Islands.

Tabla 1.- Nombres y autorías taxonómicas de todos los taxa de la familia Parabathynellidae encontrados en la Península Ibérica e Islas Baleares.

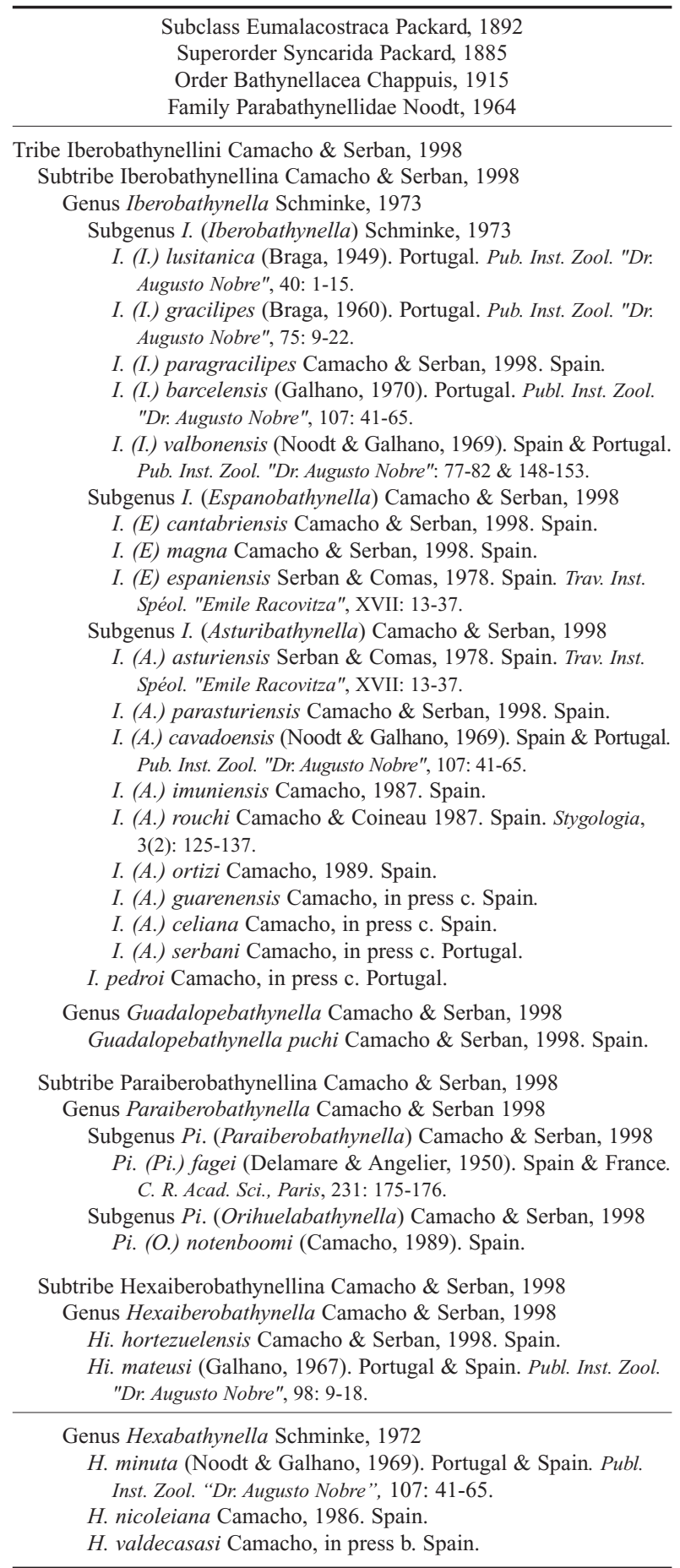


Table 2.- World distribution of the Parabathynellidae.

Tabla 2.- Distribución mundial del número de géneros y especies de la familia Parabathynellidae.

\begin{tabular}{|c|c|c|c|c|}
\hline & \multicolumn{3}{|c|}{ Family Parabathynellidae } & \multirow[b]{2}{*}{$\%$ of total } \\
\hline & number of genera & $\%$ of total & number of species & \\
\hline EUROPE & 6 & (17) & 34 & $(31,2)$ \\
\hline France & 3 & $(8,6)$ & 3 & $(2,7)$ \\
\hline Spain & 5 & $(14,3)$ & 26 & $(23,8)$ \\
\hline AMERICA & 13 & $(37,1)$ & 23 & $(21,1)$ \\
\hline North America & 3 & $(8,6)$ & 6 & $(5,5)$ \\
\hline South America & 11 & $(31,4)$ & 17 & $(15,6)$ \\
\hline ASIA & 7 & (20) & 20 & $(18,4)$ \\
\hline AFRICA & 14 & (40) & 23 & $(21,1)$ \\
\hline AUSTRALIA \& N. ZEALAND & 5 & $(14,3)$ & 14 & $(12,8)$ \\
\hline TOTAL & 35 & & 109 & \\
\hline
\end{tabular}

region, a comparative assessment of the knowledge on these taxa in the study area, in Europe and in the world is necessary.

\section{Material and Methods}

Data source derive from the literature (record appeared until 1980) and from our own surveys (Camacho 1986, 1987a \& b, 1988, 1989a, b and c, 1998, 2000, 2003a, b \& c; Camacho \& Coineau, 1989; Camacho et al., 1997 and 2000; Camacho \& Serban, 1998, 2000; and personal observations). The paper by Guil \& Camacho (2001) mentions the presence of the species $I$. (E.) espaniensis Serban \& Comas, 1978 in the localities following: Torca Treslajorá (10), Fuente del Carnero (11), Torcón de Pelacristo (21) and Torca de la Grañaja (20), but in a later revision we found that these records correspond to the sister species $I$. (E.) cantabriensis Camacho \& Serban, 1998, and to I. (E.) magna Camacho \& Serban, 1998 (see Appendix).

Since 2001 four new species of Iberobathynella and one of Hexabathynella have been published (Camacho, in press b; Camacho, in press c).

Table 1 shows the recognized names of taxa and the taxonomic authorities for the Parabathynellidae in the study area. There are 18 species of Iberobathynella (belonging to three subgenera), one species of Guadalopebathynella, two species of Paraiberobathynella Camacho \& Serban, 1998, two species of the Hexaiberobathynella genus, and three species of Hexabathynella.
Table 2 shows the world distribution, by continent, of the species of the Parabathynellidae.

Appendix lists the sites where the 26 species of the Parabathynellidae and eleven Iberobathynella sp., one Paraiberobathynella sp. and one Hexabathynella sp. have been found. For each site (139 places in Spain and Portugal) the following data are provided: an identification number, used also in Figures 1 to 4; the province; the country and the UTM coordinates. We also specify the habitat type (cave, spring, well and rivers -interstitial water associated with epigean rivers or streams).

\section{Distribution}

The distribution of the 26 species of Parabathynellidae on the Iberian Peninsula \& Balearic Islands is shown in detail in Figures 1 to 4.

Each map shows the distribution of a particular genus. The numbers indicate the different places, and the different symbols indicate the different subgenera or species.

Figure 1 shows the 74 localities where the 18 species of Iberobathynella have been found (plus $10 \mathrm{I}$. sp. localities). Taxa have been divided into 5 groups (Fig 1A): the Iberobathynella (Iberobathynella) subgenus in the western part of the Iberian Peninsula; the Iberobathynella (Espanobathynella) subgenus in a small area in the North of Spain (Picos de Europa); the Iberobathynella (Asturibathynella) subgenus in the North of the Iberian Peninsula above the Duero basin, plus one species found in Sevilla; Iberobathynella pedroi Camacho (in press c), species 

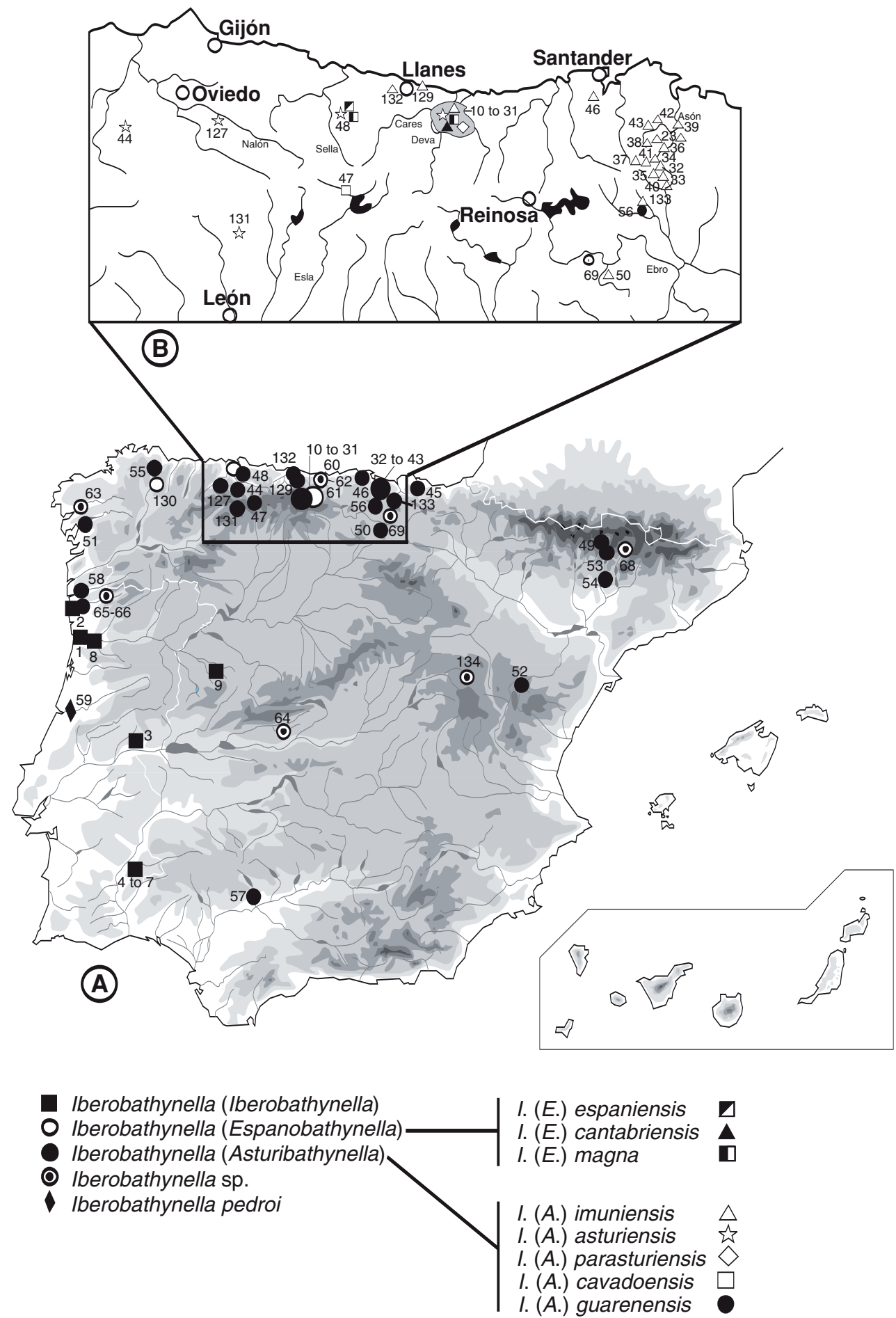

Fig. 1-Distribution of the genus Iberobathynella on the Iberian Peninsula. a) Iberian Peninsula and b) detail of Cantabric region, the area with the highest density of sampling points. Each number corresponds to a sampling site (see Appendix).

Fig. 1- Distribución del género Iberobathynella en la Península Ibérica. a) Península Ibérica completa y b) detalle de la region Cantábrica, donde se da la mayor densidad de puntos de muestre. Los números corresponden a las localidades del Apéndice. 


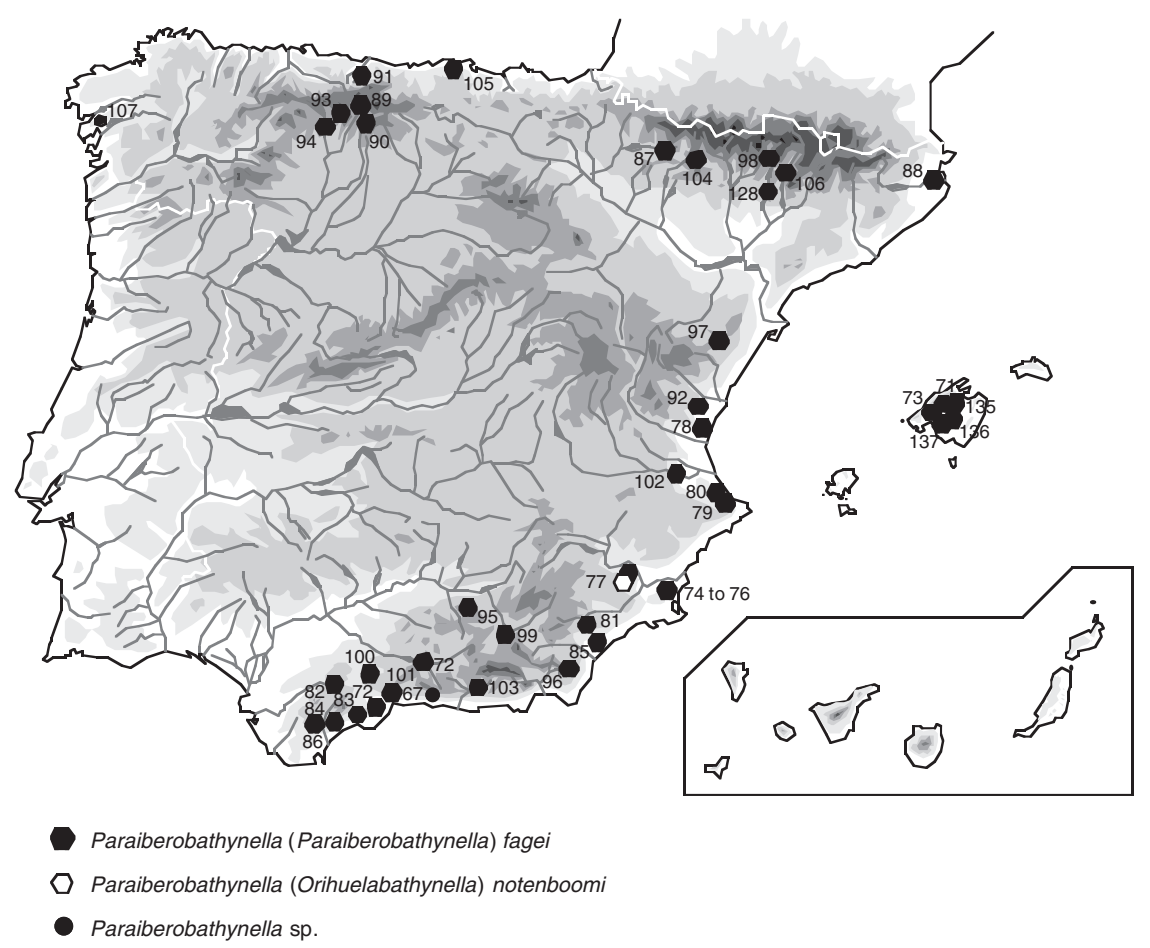

Fig. 2- Distribution of the species of the genus Paraiberobathynella of the Iberian Peninsula and the Balearic Islands. Each number corresponds to a sampling site (see Appendix).

Fig. 2.-Distribución de las especies del género Paraiberobathynella en la Península Ibérica e Islas Baleares. Los números corresponden a las localidades del Apéndice.

limited to the western-central region of Portugal; and a fifth group composed of 10 Iberobathynella sp. distributed in the north, northeast, northwest and center of the Iberian Peninsula.

Figure 2 details the 43 localities where the 2 species of the genus Paraiberobathynella have been found. All places are situated on the edge of the Peninsula, from Cantabria to Cádiz, and on the Island of Mallorca. This genus also lives in North Africa (Paraiberobathynella maghrebensis Boutin \& Coineau, 1987).

Figure 3 shows the 19 localities of Hexaiberobathynella. Another genus, the monotypic Guadalopebathynella is found in a single locality (70).

Figure 4 shows the distribution of the genus Hexabathynella, with two localities in the North of Portugal (124 and 65), one in the south of Spain (123) and three more in Central Spain.

There are 109 species of Parabathynellidae known in the world (Table 2). Europe is the continent which has been most sampled. This sampling effort has been very unequal over the years and very different in each country. However it can still be said that the some sampling effort has been devoted in France, Spain, Portugal, Slovenia, Italy, Bulgaria, Rumania, Belgium and Germany during the last 70 years. America, both North and South, has been hardly sampled. Few species have been found there, and most new species described are only known from the type locality. The same holds for Asia, Africa, Australia and New Zealand. Most of the genera described worldwide (35) have only been found, to date, in a single country.

\section{Results}

Table 2 shows the world distribution of the genera and species of the Parabathynellidae by continent. It can be seem that almost one quarter of all the species known in the world live on the Iberian Peninsula and that of all the genera described, 14\% come from Iberian Peninsula. 
Table 3.- Number of localities and habitat types where the different taxa of Parabathynellidae family are found on the Iberian Peninsula and Balearic Islands. $\mathrm{P}=$ Portugal and $\mathrm{S}=$ Spain

Tabla 3.- Resumen del número de localidades y del número de habitat en que aparecen los diferentes taxa de la familia Parabathynellidae en la Península Ibérica y las Islas Baleares. *: P= Portugal and $\mathrm{S}=$ España.

\begin{tabular}{|c|c|c|c|c|c|}
\hline Taxa & Number of localities & Number of wells & Number of caves & Number of streams & Number of springs \\
\hline Iberobathynella & 74 & 7 & 41 & 20 & 6 \\
\hline Iberobathynella (I.) & 9 & 7 & 0 & 2 & 0 \\
\hline I. (I.) lusitanica & 2 & 1 & 0 & 1 & 0 \\
\hline I. (I.) gracilipes & 1 & 1 & 0 & 0 & 0 \\
\hline I. (I.) paragracilipes & 4 & 4 & 0 & 0 & 0 \\
\hline I. (I.) barcelensis & 1 & 0 & 0 & 1 & 0 \\
\hline I. (I.) valbonensis & 2 & 1 & 0 & 1 & 0 \\
\hline Iberobathynella (E.) & 15 & 0 & 15 & 0 & 0 \\
\hline I. (E.) cantabriensis & 11 & 0 & 11 & 0 & 0 \\
\hline I. (E.) magna & 11 & 0 & 11 & 0 & 0 \\
\hline I. (E.) espaniensis & 1 & 0 & 1 & 0 & 0 \\
\hline Iberobathynella (A.) & 45 & 0 & 29 & 12 & 4 \\
\hline I. (A.) asturiensis & 5 & 0 & 5 & 0 & 0 \\
\hline I. (A.) parasturiensis & 4 & 0 & 4 & 0 & 0 \\
\hline I. (A.) cavadoensisi & 3 & 0 & 0 & 3 & 0 \\
\hline I. (A.) imuniensis & 26 & 0 & 19 & 3 & 4 \\
\hline I. (A.) rouchi & 3 & 0 & 0 & 3 & 0 \\
\hline I. (A.) ortizi & 1 & 0 & 1 & 0 & 0 \\
\hline I. (A.) guarenensis & 1 & 0 & 1 & 0 & 0 \\
\hline I. (A.) celiana & 1 & 0 & 0 & 1 & 0 \\
\hline I. (A.) serbani & 1 & 0 & 0 & 1 & 0 \\
\hline I. pedroi & 1 & 0 & 0 & 1 & 0 \\
\hline Guadalopebathynella puchi & 1 & 0 & 0 & 1 & 0 \\
\hline Paraiberobathynella & 43 & 12 & 6 & 25 & 0 \\
\hline Pi. fagei & 42 & 12 & 6 & 24 & 0 \\
\hline Pi. notenboomi & 1 & 1 & 0 & 0 & 0 \\
\hline Hexaiberobathynella & 21 & 2 & 1 & 17 & 1 \\
\hline Hi. hortezuelensis & 1 & 1 & 0 & 0 & 0 \\
\hline Hi. mateusi & 20 & 1 & 1 & 17 & 1 \\
\hline Hexabathynella & 6 & 0 & 0 & 6 & 0 \\
\hline H. minuta & 3 & 0 & 0 & 3 & 0 \\
\hline H. nicoleiana & 1 & 0 & 0 & 1 & 0 \\
\hline H. valdecasasi & 1 & 0 & 0 & 1 & 0 \\
\hline TOTAL & 139 & 21 & 49 & 62 & 7 \\
\hline
\end{tabular}

Half of the world genera are African, but the number of African makes up only $25 \%$ of the total. In France, only 3 species of this family are known: Paraiberobathynella (Pi.) fagei, which lives in 3 localities close to Perpignan; Parabathynella motasi or stygia, known only from a single locality; in 10 French localities there are specimens as yet unidentified (under study by the author) but which could correspond to Parabathynella; and Hexabathynella knoepfflery, found in Corsica.
If we take into account that the sampling effort in neighbouring France has been similar or even greater in the past than that carried out in Spain in the last 18 years, we can conclude that the diversity, in the number of species, is far superior in the Iberian Peninsula.

In the rest of Europe, which has also been well sampled, only 2 species of Parabathynella, and 5 more, all Bulgarian, of Hexabathynella have been found. 
Fig. 3- Distribution of the Hexaiberobathynella and Guadalopebathynella species of the Iberian Peninsula. Each number corresponds to a sampling site (see Appendix).

Fig. 3- Distribución de las especies de los géneros Hexaiberobathynella y Guadalopebathynella en la Península Ibérica. Los números corresponden a las localidades del Apéndice.
Fig. 4.- Distribution of the species of the genus Hexabathynella of the Iberian Peninsula. Each number corresponds to a sampling site (see Appendix).

Fig. 4.- Distribución de las especies del género Hexabathynella en la Península Ibérica. Los números corresponden a las localidades del Apéndice.

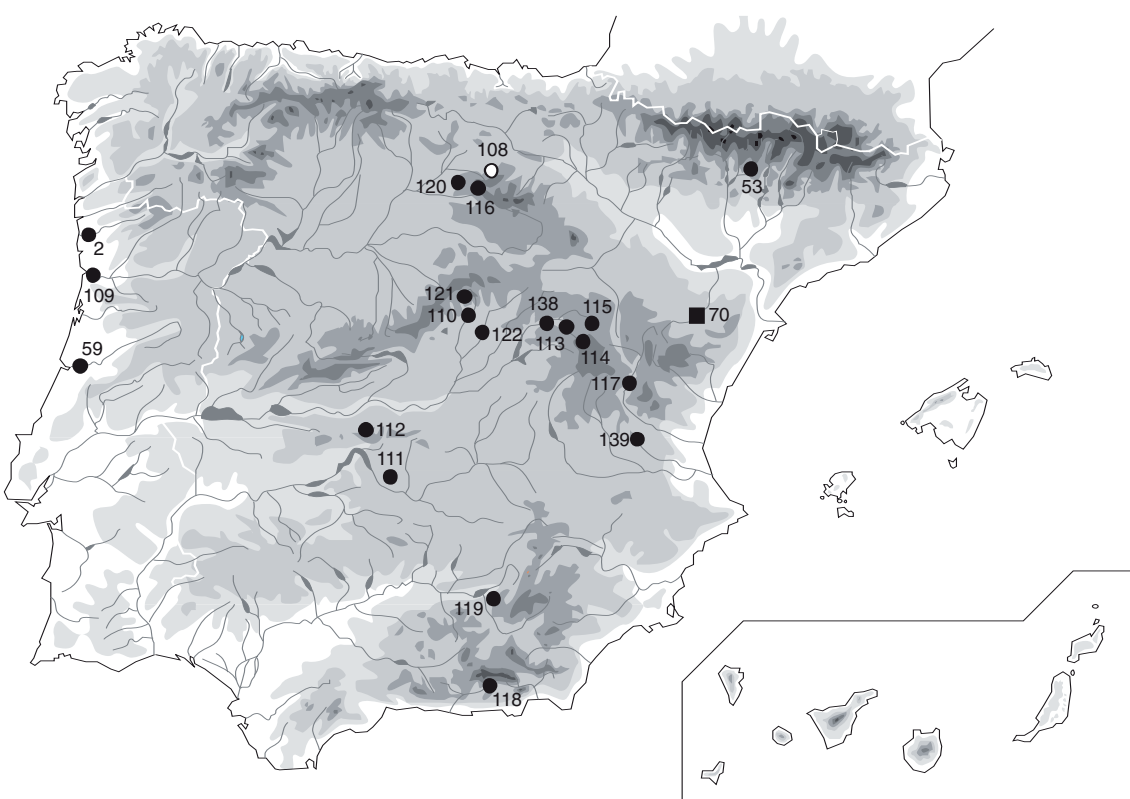

Hexaiberobathynella hortezuelensis

- Hexaiberobathynella mateusi

Guadalopebathynella puchi

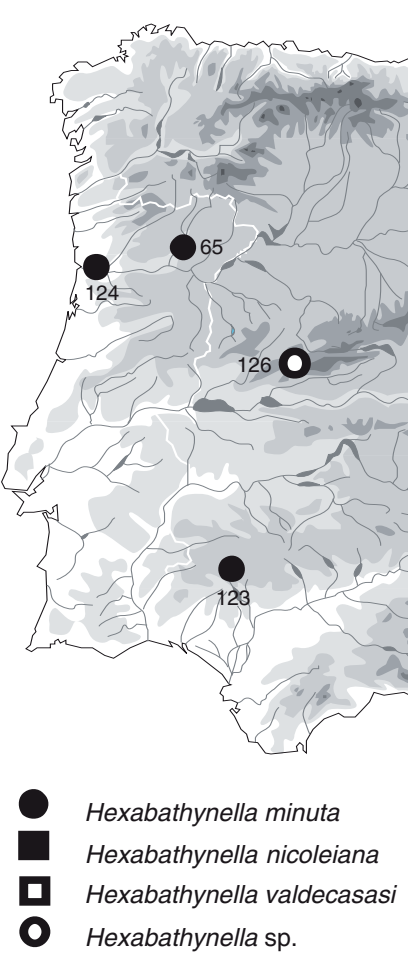


Table 4.- Coexistence of species of Parabathynellidae in the Iberian Peninsula. 1.- Iberobathynella (I.) lusitanica; 4.- I. (I.) barcelensis; 6.-I. (E.) cantabriensis; 7.-I. (E.) magna; 8.-I. (E.) espaniensis; 9.-I. (A.) asturiensis; 10.-I. (A.) parasturiensis; 11.-I. (A.) cavadoensis; 12.-I. (A.) imuniensis; 13.-I. (A.) rouchi; 18.-I. pedroi; 20.-Paraiberobathynella fagei; $21 .-$ Paraiberobathynella notenboomi; 23.-Hexaiberobathynella mateusi; 24.-Hexabathynella minuta; 25.-Hexabathynella nicoleiana; 27.- Iberobathynella sp.; 28.- Paraiberobathynella sp. Localities with more than one species: 2.- Cavado river (interstitial); 10.- Torca Treslajorá (cave); 11.Fuente del Carnero (cave); 12.- Torca Divisada (cave); 13.- Torcón de los Lobos (cave); 14.- Torco de los Lobos (cave); 20.- Torca de la Grañaja (cave); 21.- Torcón de Pelacristo (cave); 29.- Torca del Tejo (cave); 48.- Cova del Infierno (cave); 53.- Cinca river (interstitial); 59.- Mondego river (interstitial); 65.- Pinhao river (interstitial); 67.- Vélez river (interstitial); 77.- Los Picos (well) and 110.- Jarama river (interstitial).

Tabla 4.- Coexistencia entre especies de la familia Parabathynellidae presentes en la Péninsula Ibérica. 1.- Iberobathynella (I.) lusitanica; 4.- I. (I.) barcelensis; 6.-I. (E.) cantabriensis; 7.-I. (E.) magna; 8.-I. (E.) espaniensis; 9.-I. (A.) asturiensis; 10.-I. (A.) parasturiensis; 11.-I. (A.) cavadoensis; 12.-I. (A.) imuniensis; 13.-I. (A.) rouchi; 18.-I. pedroi; 20.-Paraiberobathynella fagei; 21.Paraiberobathynella notenboomi; 23.-Hexaiberobathynella mateusi; 24.-Hexabathynella minuta; 25.-Hexabathynella nicoleiana; 27.- Iberobathynella sp.; 28.- Paraiberobathynella sp. Localidades en que se ha encontrado más de una especie: 2.- Río Cavado (intersticial); 10.- Torca de Treslajorá (cueva); 11.- Fuente del Carnero (cueva); 12.- Torca Divisada (cueva); 13.- Torcón de los Lobos (cueva); 14.- Torco de los Lobos (cueva); 20.- Torca de la Grañaja (cueva); 21.- Torcón de Pelacristo (cueva); 29.- Torca del Tejo (cueva); 48.- Cova del Infierno (cueva); 53.- Río Cinca (intersticial); 59.- Río Mondego (intersticial); 65.- Río Pinhao (intersticial); 67.- Río Vélez (intersticial); 77.- Los Picos (pozo) y 110.- Río Jarama (intersticial).

\begin{tabular}{|c|c|c|c|c|c|c|c|c|c|c|c|c|c|c|c|c|}
\hline \multirow[b]{2}{*}{ Species } & \multicolumn{16}{|c|}{ Sampling points } \\
\hline & 2 & 10 & 11 & 12 & 13 & 14 & 20 & 21 & 29 & 48 & 53 & 59 & 65 & 67 & 77 & 110 \\
\hline 1 & + & - & - & - & - & - & - & - & - & - & - & - & - & - & - & - \\
\hline 4 & + & - & - & - & - & - & - & - & - & - & - & - & - & - & - & - \\
\hline 6 & - & + & + & + & + & + & - & + & + & - & - & - & - & - & - & - \\
\hline 7 & - & + & + & + & + & + & & + & + & + & + & - & - & - & - & - \\
\hline 8 & - & - & - & - & - & - & - & - & - & + & - & - & - & - & - & - \\
\hline 9 & - & - & - & - & - & - & - & - & - & + & - & - & - & - & - & - \\
\hline 10 & - & + & - & + & - & - & + & - & - & - & - & - & - & - & - & - \\
\hline 11 & + & - & - & - & - & - & - & - & - & - & - & - & - & - & - & - \\
\hline 12 & - & + & - & - & - & - & - & - & - & - & - & - & - & - & - & - \\
\hline 13 & - & - & - & - & - & - & - & - & - & - & + & - & - & - & - & - \\
\hline 18 & - & - & - & - & - & - & - & - & - & - & - & + & - & - & - & - \\
\hline 20 & - & - & - & - & - & - & - & - & - & - & - & - & - & + & + & - \\
\hline 21 & - & - & - & - & - & - & - & - & - & - & - & - & - & - & + & - \\
\hline 23 & + & - & - & - & - & - & - & - & - & - & + & + & - & - & - & + \\
\hline 24 & - & - & - & - & - & - & - & - & - & - & - & - & + & - & - & - \\
\hline 25 & - & - & - & - & - & - & - & - & - & - & - & - & - & - & - & + \\
\hline 27 & - & - & - & - & - & - & - & - & - & - & - & - & + & - & - & - \\
\hline 28 & - & - & - & - & - & - & - & - & - & - & - & - & - & + & - & - \\
\hline
\end{tabular}

None of the other 4 continents can equal the Iberian Peninsula in the number of known species. Africa, which is far bigger that the Iberian Peninsula harbours only 23 known species and the same holds for America (23 species). But the sampling effort in these continents cannot be compared with that carried out in the Iberian Peninsula in the last few years and it is to be expected that when more intensive sampling takes place the figures will go up significantly.

Table 3 and Appendix it show that the genus Iberobathynella is themost common in the study area, being present in 74 sites (Fig. 1). The 18 species belong to three subgenera: Iberobathynella (Iberobathynella) (9 localities, four in Portugal and five in Spain), containing five especies, three being unique to Portugal, one which only lives in Spain, and another found in both countries; the Iberobathynella (Espanobathynella) subgenus inhabits 15 localities, with one species in a single locality, the other two species coexisting in 7 localities and each inhabiting 4 additional localities separately; the Iberobathynella (Asturibathynella) subgenus is found in 45 localities, has the greatest number of species of all the subgenera (nine); four of its species are only found in a single site, one in Portugal, and the other three in Spain; another five species only appear in Spain in 5, 4, 3, 3 and 26 localities respectively; Iberobathynella pedroi (subgenus unknown) has only been found in a single locality in Portugal. 


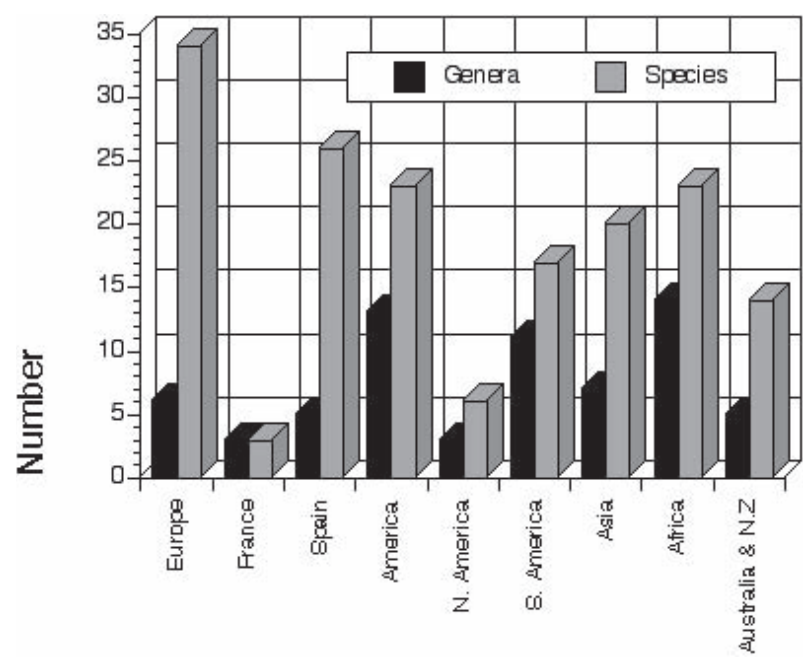

Fig. 5.- Number of genera and species of the world Parabathynellidae.

Fig. 5.- Histograma del número de géneros y especies de la familia Parabathynellidae en el mundo.

The genus Paraiberobathynella occurs in 43 localities (Fig. 2; Table 3): Pi. (Paraiberobathynella) fagei (42 localities), and Pi. (Orihuelabathynella) notenboomi (single locality, number 77), and Pi. sp. found in a single locality (67).

Hexaiberobathynella has been found in 21 localities (Fig. 3; Table 3); one species, Hi. mateusi was found in 20 sites, while the other species, Hi. hortezuelensis is known from a single site only (108).

Another genus with a reduced distribution (a single locality, 70) is the monotypic Guadalopebathynella (Fig. 3; Table 3).

Hexabathynella has been found in 6 localities (Fig. 4; Table 3); one species, $H$. minuta, lives in three sites, two in the North of Portugal, and one in the south of Spain. The other two species, H. nicoleiana and $H$. valdecasasi, are only found in Central Spain, each in a single place. An additional species, $H$. sp., lives also in Central Spain.

Table 3 shows also the habitat types occupied by the 5 genera and 26 species: rivers (interstitial environment), caves, wells and springs.

Figure 6A shows of the percentage of sampling points per habitat type: $45 \%$ - the biggest- for rivers and $5 \%$ for springs- the smallest. In these habitats the representation of genera is very unequal, as can be seen in Fig. 6B. In rivers all 5 genera are present, with Paraiberobathynella being the most common, found in $40 \%$ of the sampling points) although
Iberobathynella is also very common (32\%); Guadalopebathynella has only been found once and does not appear in any other habitat.

In caves only 3 genera have been found (neither Guadalopebathynella nor Hexabathynella occur) and here it is the genus Iberobathynella which occurs most frequently (84\%); Paraiberobathynella only appears in $13 \%$ of the sampling points, and Hexaiberobathynella in 3\%.

In wells the same subgenera as in caves are found, but again and as for rivers Paraiberobathy-nella is most common (57\%), whereas the least common is Hexaiberobathynella $(10 \%)$.

In springs we only found Iberobathynella (86\%) and Hexaiberobathynella (14\%).

Figure 6C shows the percentage of sampling points where each of the 5 genera have been found. Iberobathynella is most common (54\% of the total), followed by Paraiberobathynella (31\%), whereas the rarest is Guadalopebathynella $(0.9 \%)$. Figure $6 \mathrm{D}$ shows the habitat preference for each genus. Iberobathynella occurs in all habitats, although it is more common in caves (55\%). Paraiberobathynella is most common in rivers $(53 \%)$ and is never found in springs. Hexaiberobathynella appears in all habitats, but most commonly in rivers $(80 \%)$. Guadalopebathynella and Hexabathynella only live in rivers.

The most common species is Paraiberobathynella fagei (42 sampling points, covering all habitats except springs), followed by Iberobathynella (A.) imuniensis (26 sites, all habitats except wells) and Hexaiberobathynella mateusi (20 localities). The only species that appears in all habitats is Hexaiberobathynella mateusi (Table 3 ).

The different species of the genus Iberobathynella frequently coexist (I. (E.) magna and $I$. (E.) cantabriensis in 7 caves; e.g. see Table 4) while they rarely coexist with species from other genera. Species from the other genera show also little propensity to coexist with other species of their owngenus or of other genera.

\section{Discussion and Conclusion}

The subterranean waters of the Iberian Peninsula and the Balearic Islands have been sampled very unequally. There are areas (e.g. the North of Spain) where a great deal of sampling has been carried out, whereas in other (e.g. the karsts of Cuenca and Andalucia) the invested sampling effort has been minimal. There is still a lot of virgin terretory remaining to be explored. As the interstitial waters associated with rivers is 
A

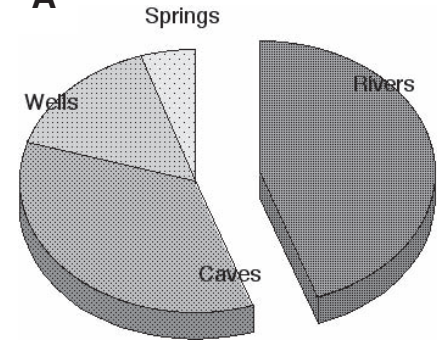

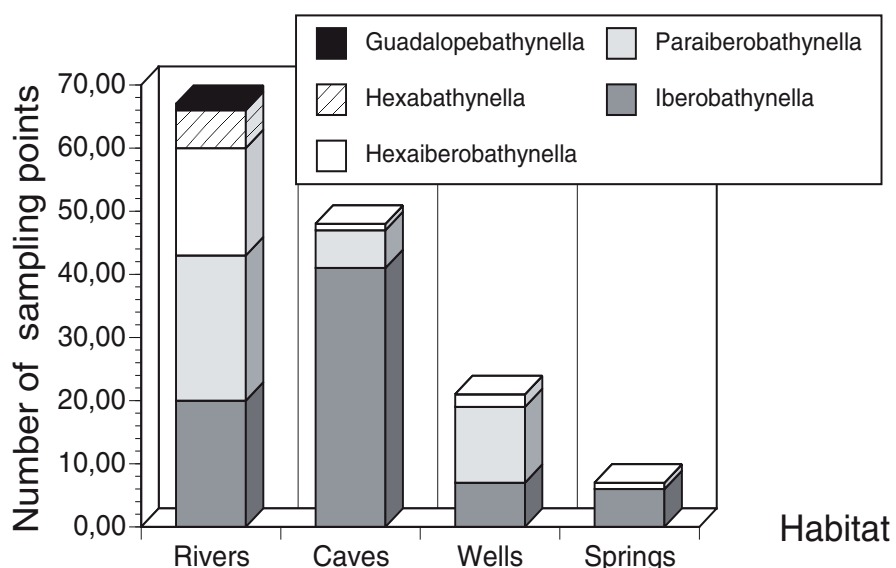

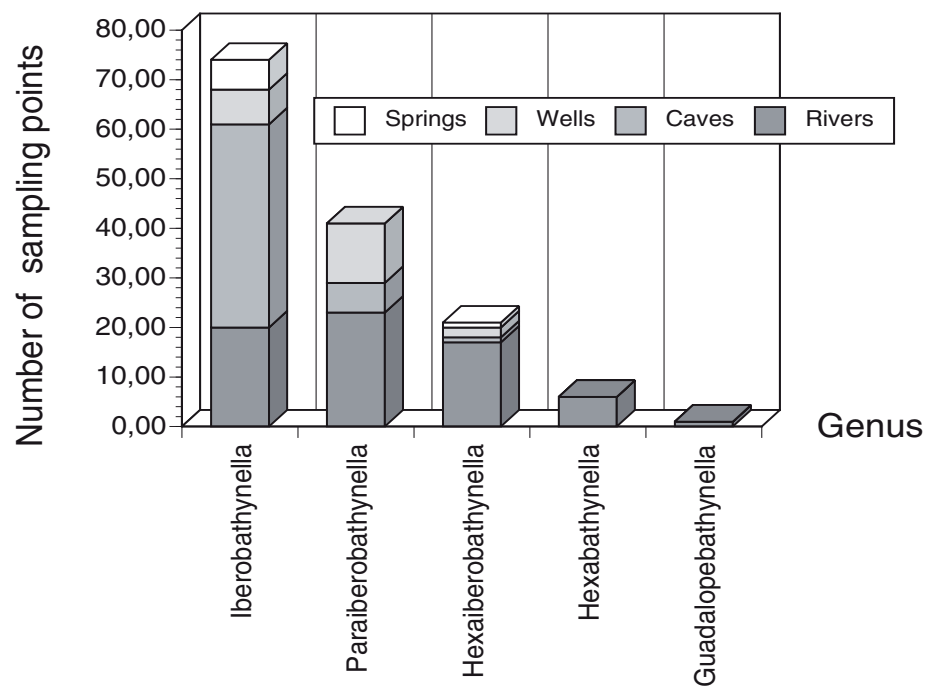

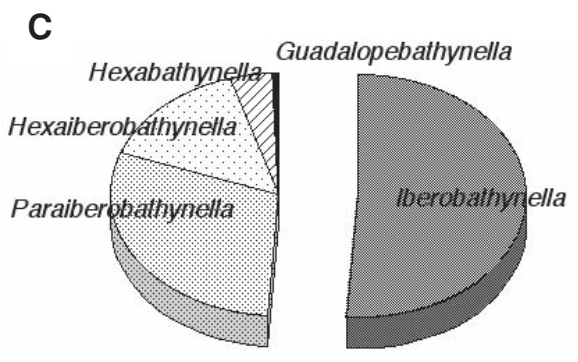

Fig. 6.-A) Number of locations sampled per habitat type as a percentage of the total. B) Number of samples per habitat rendering each genus. C) Number of points sampled rendering each genus as a percentage of the total. D) Number of samples containing each genus per habitat.

Fig. 6.- A) Distribucion del número de puntos de muestreo en los medios acuáticos subterráneos considerados, en \%. B) Reparto de géneros por medios. C) Número de puntos de muestreo en que se ha encontrado cada género, en \% y D) reparto de medios por géneros.

the most easily accessible habitat, it has been the most "intensively" sampled. However the very big subterranean systems are practically unknown from a faunistic viewpoint, especially those reaching great depth (in Spain there are 14 sinkholes more than 1000 $m$ depth, see Puch, 1998) and length (many caves are more than $30 \mathrm{~km}$ long).
Nevertheless, and in spite of the big gap of knowledge that still remain on this habitat, batinels have been found in almost all places sampled, and the number of species known to date (26, see Table 4 ) is the biggest the world around.

The most abundant genus in the study area, Iberobathynella (18 species), is the world most 
diversified of the Parabathynellidae (only the cosmopolitan genus Hexabathynella embraces a similar number of species). Iberobathynella is found in all habitat types studied, although it is more common in cave waters.

As sampling is intensified and sampling areas are expanded the number of new species found is growing up. This trend affects not only the family Parabathynellidae, but also the Bathynellidae, which also appears in almost every subterranean habitat sampled (data still unpublished).

\section{ACKNOWLEDGEMENTS}

We are very grateful to all people who kindly supplied us with material (Notenboom \& Meijiers; Rouch et col.; Ortiz; G.E.Edelweiss). We gratefully acknowledge C. Puch, F. Molinero, J. Robador, A. De Juan, A. G.-Valdecasas and J. Bedoya, who helped us in different ways. We thank Mark Creb who helped us with the English translations. This work was supported by projects REN2000-2040 GLO, EVK2-CT-200100121 (PASCALIS) and Convenio Junta de Castilla y LeónCSIC (2002-2004).

\section{References}

Boutin, C. \& CoInEAU, N., 1987. Iberobathynella maghrebensis (Crustacea, Syncarida, Bathynellacea) sur le continent Africain. Implications paléogéographiques. Comptes Rendues de l'Académie des Sciences, Paris, vol. 304, III(13): 355-358.

CAMACHO, A. I., 1986. A new species of the genus Hexabathynella (Syncarida, Bathynellacea, Parabathynellidae) from Spain. Bijdragen tot de Dierkunde, 56(1): 123-131.

CAmacho, A. I., 1987a. La familia Parabathynellidae (Crustacea, Syncarida, Bathynellacea) en la Península Ibérica. Taxonomía, filogenia y biogeografía. Unpublished Ph.D. Thesis. Universidad Autónoma de Madrid. 889 pp.

CAMACHO, A. I., 1987b. A new subterranean syncarid (Crustacea) from Spain: Iberobathynella imuniensis n. sp. (Bathynellacea, Parabathynellidae). Archiv für Hydrobiologie, 111(1): 137-149.

CAmacho, A. I., 1988. Historia, Clave de Determinación y Distribución del Género Iberobathynella (Crustacea, Syncarida, Parabathynellidae) en la Península Ibérica. Actas del III Congreso Ibérico de Entomología: 43-56.

CAMACHO, A. I., 1989a. A new species of the "mateusi" group: Iberobathynella ortizi sp. n. (Crustacea, Syncarida, Parabathynellidae). Zoologica Scripta, 18(3): 405-410.

CAmacho, A. I., 1989b. Los Parabatinélidos (Crustacea, Syncarida, Bathynellacea) recogidos en la Península
Ibérica. Boletín de la Asociación Española de Entomología, 13: 71-90.

CAMACHO, A. I., 1989c. Iberobathynella notenboomi $\mathrm{n}$. sp. (Syncarida, Parabathynellidae) from a well in Alicante, South-East Spain. Spixiana, 12(2):105113.

CAmacho, A. I., 1998. La Vida Animal en el Mundo Subterráneo: Habitantes de las Grandes Cuevas y Simas de España. In: C. Puch (ed.). Grandes Cuevas y Simas de España. Exploracions, Monográfico Espeleo Club de Gracia. Barcelona: 19-46.

CAMAcho, A. I., 2000. La fauna acuática subterránea de Lamasón y Peñamellera Baja (Cantabria): 15 años de investigaciones Bioespeleológicas. Boletín Cántabro de Espeleología, 14: 153-164.

CAMACHO, A. I., 2003a. Historical biogeography of Hexabathynella, a cosmopolitan genus of groundwater Syncarida (Crustacea, Bathynellacea, Parabathynellidae). Biological Journal of the Linnean society, 78: 457-466.

Camacho, A. I., in press b. An overview of Hexabathynella genus (Crustacea, Syncarida, Parabathynellidae) with the description of a new species. Journal of Natural History (in press).

Camacho, A. I., in press c. Four new species of the groundwater crustaceans (Syncarida, Bathynellacea, Parabathynellidae) endemic to the Iberian Peninsula (Portugal and Spain). Journal of Natural History (in press).

Camacho, A. I., Bello, E. \& Estabrook, G. F., 1997. A statistical approach to the evaluation of characters to estimate evolutionary relationships among the species of the aquatic subterranean genus Iberobathynella (Crustacea, Syncarida). Biological Journal of the Linnean Society, 60: 221-241.

Camacho, A. I. \& Coineau, N., 1989. Les Parabathynellaces (Crustacés syncarides) de la Péninsule Ibérique, répartition et paléobiogéographie. Mémoires de Biospéologie, 16: 111-124.

Camacho, A. I. \& Serban, E., 1998. Tribu des Iberobathynellini nov., diagnoses des taxa nouveaux (Parabathynellidae, Bathynellacea, Podophallocarida). Travaux de l'Institute de Spéologie "Emile Racovitza”, 34: 15-75.

CAmacho, A. I. \& Serban, E., 2000. Revisión del grupo Iberobathynella (Iberobathynella) Schminke, 1973 (Crustacea, Syncarida, Parabathynellidae) endémico de la Península Ibérica. Graellsia, 56: 35-48.

Camacho, A. I., Serban, E. \& Guil, N., 2000. Phylogenetical review and biogeographic remarks on the interstitial and subterranean freshwater iberobathynells (Crustacea, Syncarida, Parabathynellidae). Journal of Natural History, 34: 563-585.

Chappuis, P. A., 1926. Parabathynella stygia n. g. n. sp., nouveau crustacé cavernicole de la Serbie Orientale. Buletinul Societâtii de Stiinte din Cluj, 3(1): 7-10. 
GuIL, N. \& CAmacho, A. I., 2001. Historical biogeography of Iberobathyella (Crustacea, Syncarida, Bathynellacea), an aquatic subterranean genus of Parabathynellids, endemic to the Iberian Peninsula. Global Ecology \& Biogeography, 10: 487-501.

Pretus, J. L, 1991. Estudio Taxonómico, Biogeográfico y Ecológico de los Crustáceos epigeos e hipogeos de las Baleares (Branchiopoda, Copepoda, Mystacocarida y Malacostraca). Unpublished Ph. D. Thesis. Universidad Autónoma de Barcelona. 513 pp.

Puch, C., 1998. Grandes Cuevas y Simas de España. Espeleo Club De Gracia. Barcelona. 816 pp.

Schminke, H. K., 1972. Hexabathynella halophila gen. n., sp. n. und die Frage nach der marinen Abkunft der Bathynellacea (Crustacea: Malacostraca). Marine Biology, 15: 282-287.
SCHMINKE, H. K., 1973. Evolution, system und verbreitungsgeschichete der Familie Parabathynellidae (Bathynellacea, Malacostraca). Akademie der Wissenschaften und der Literatur zu Mainz, Mathematisch-Naturwissenschaftliche Klasse, Mikrofauna des Meeresboden 24: 1-192.
Recibido, 13-VI-2003

Aceptado, 6-XI-2003 Publicado, 15-XII-2003 


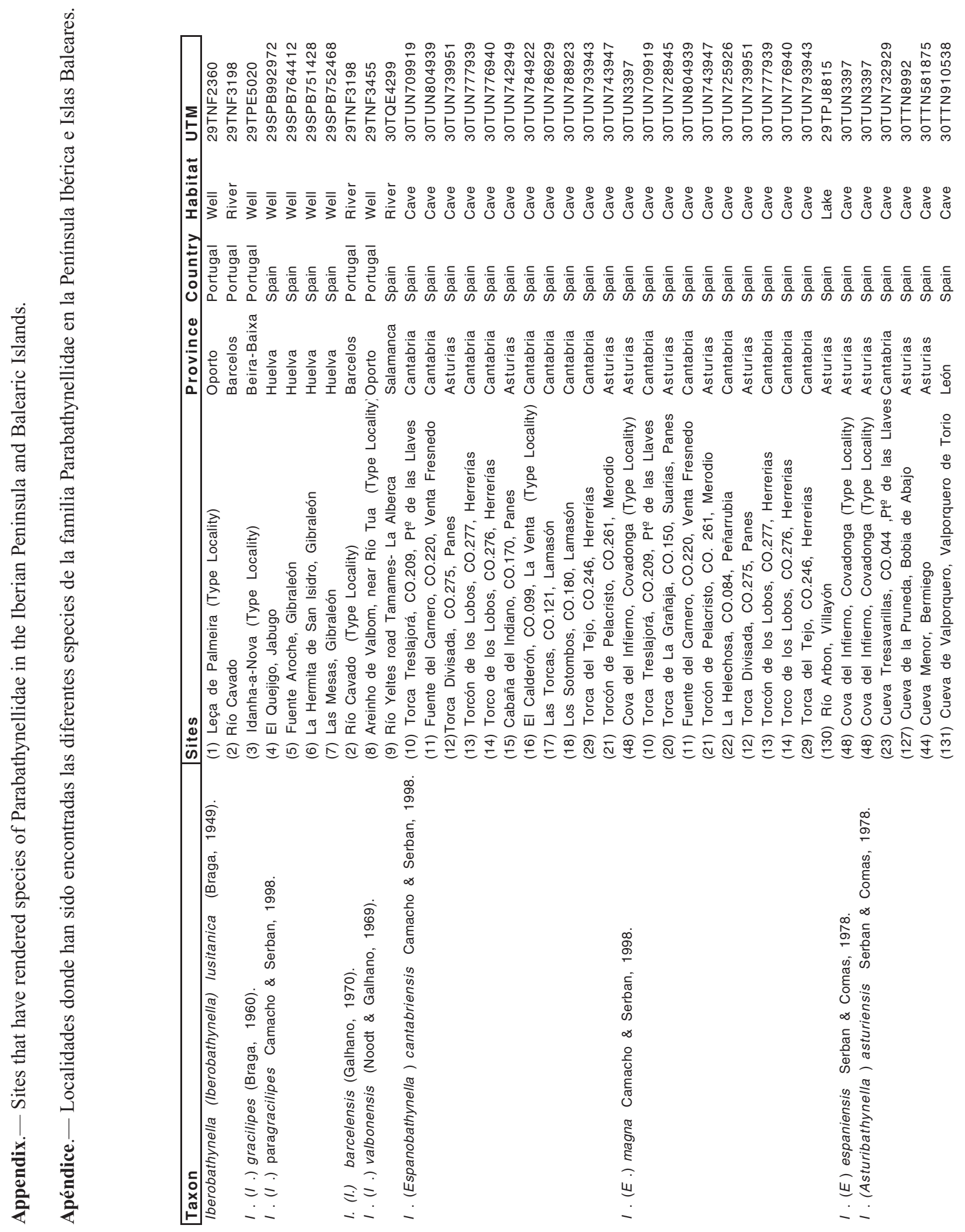




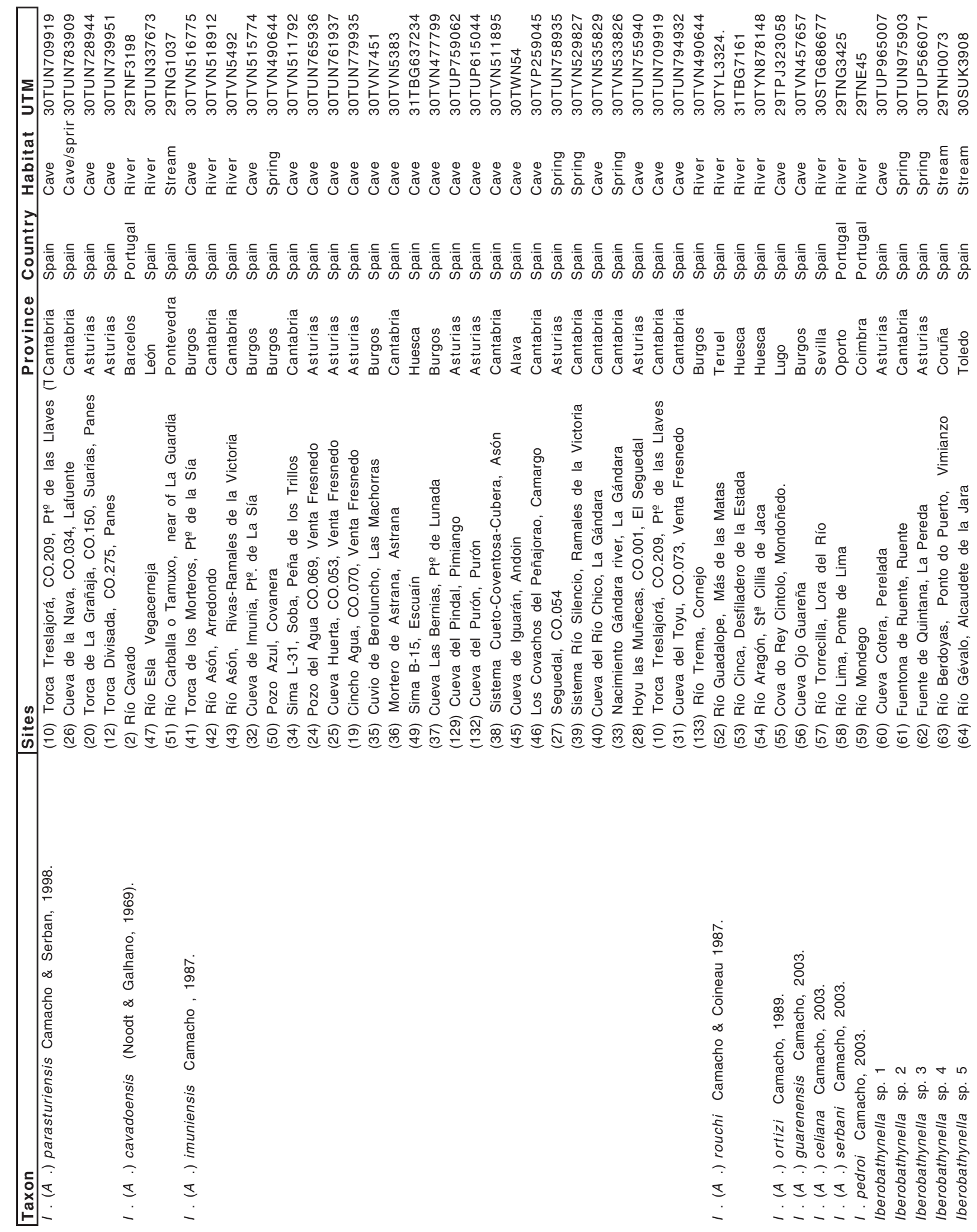




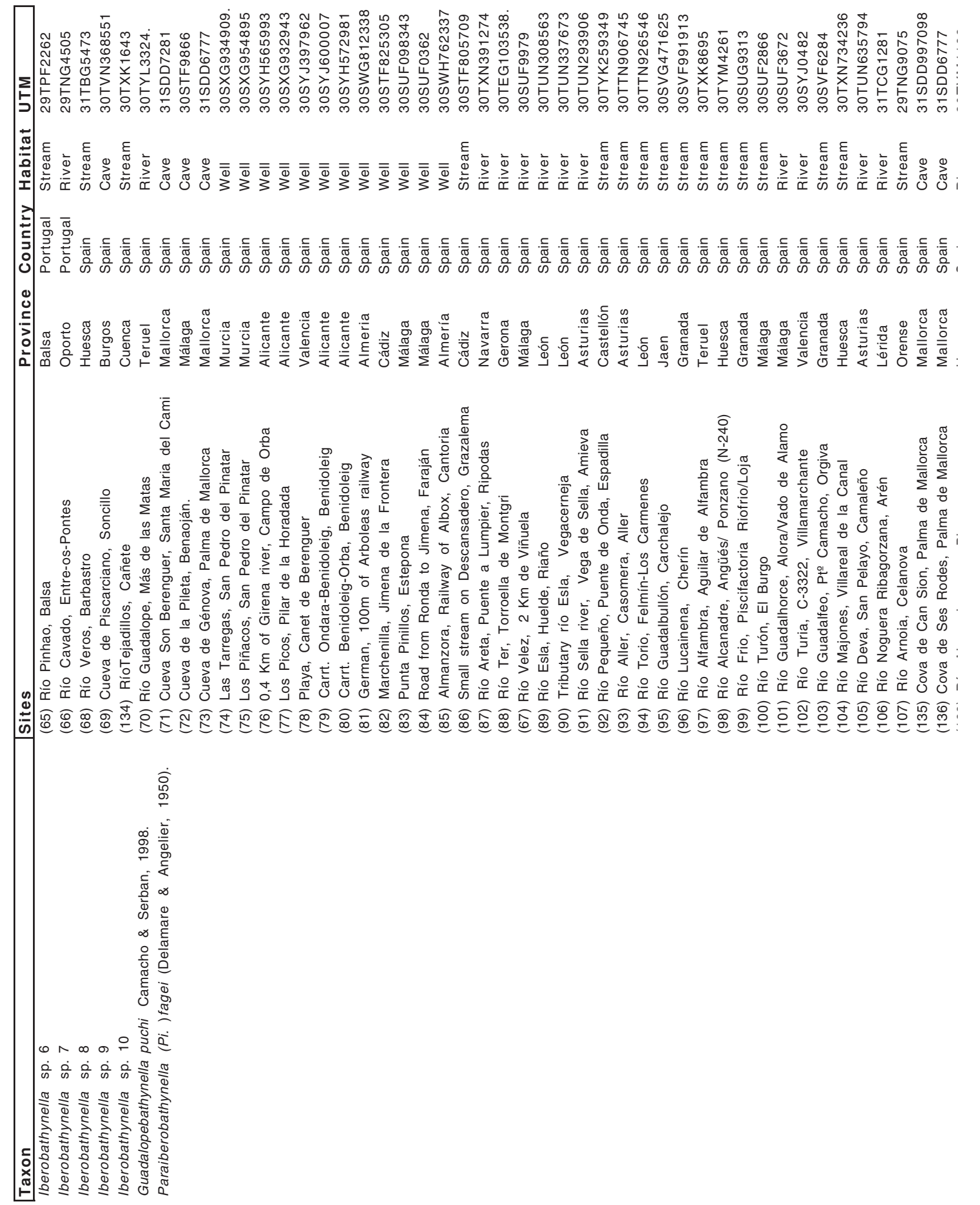


CAMACHO, A. I.

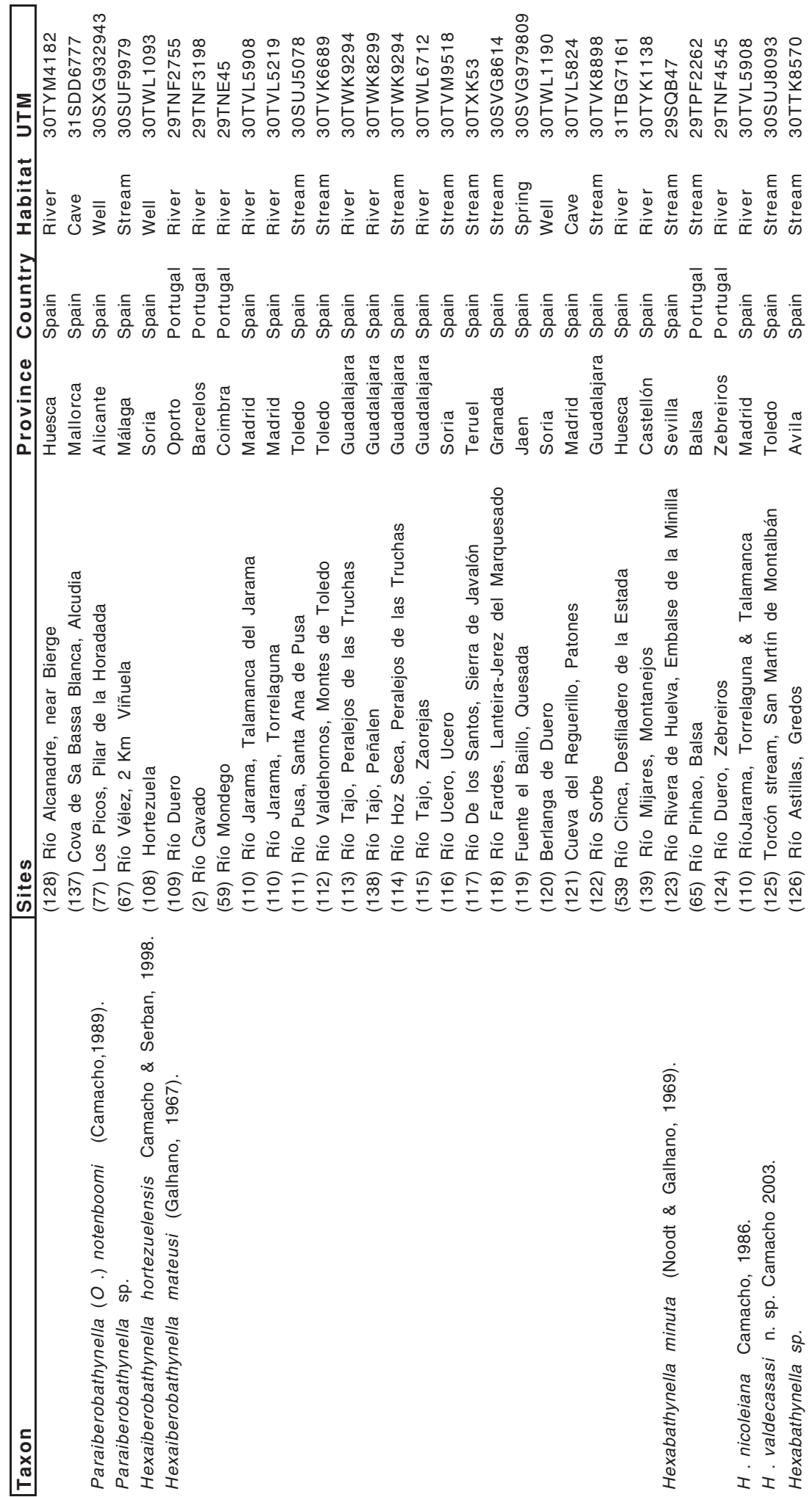

